\title{
The effect of cattle manure and mineral fertilizers on soil chemical properties and tuber yield of purple-fleshed sweet potato in the dryland region of East Nusa Tenggara, Indonesia
}

\author{
M.S. MAHMUDDIN NUR ${ }^{1,2, \boldsymbol{v}}$, I.G.B. ADWITA ARSA ${ }^{2}$, YOHANES MALAIPADA ${ }^{2}$ \\ ${ }^{1}$ Archipelagic Dryland Center of Excellence (PUI Lahan Kering Kepulauan), Universitas Nusa Cendana. Jl. Adisucipto, Penfui, Kupang 85001, \\ East Nusa Tenggara, Indonesia \\ ${ }^{2}$ Department of Agrotechnology, Faculty of Agriculture, Universitas Nusa Cendana. Jl. Adisucipto, Penfui, Kupang 85001, East Nusa Tenggara, \\ Indonesia. Tel./fax.: +62-380-881085, `email: mahmuddinundana@ gmail.com
}

Manuscript received: 27 August 2019. Revision accepted: 7 December 2019.

\begin{abstract}
Nur MSM, Arsa IGBA, Malaipada Y. 2019. The effect of cattle manure and mineral fertilizers on soil chemical properties and tuber yield of purple-fleshed sweet potato in the dryland region of East Nusa Tenggara, Indonesia. Trop Drylands 3: 56-59. Sweet potato is potential crop developed in dryland regions, yet the yield is deemed low due to poor soil conditions. Thus, fertilizers are often needed to improve soil quality, leading to increasing tuber yield. A field experiment was carried out to study the effect of combination of cattle manure and mineral fertilizer on the soil chemical properties and yield of purple sweet potato. The experiment was arranged in a Randomized Block Design, with six treatments and four replicates. The assigned treatments were P0 = without manure and without mineral fertilizer, $\mathrm{P}_{1}=100 \%$ recommended dosage of manure $(20$ tons ha-1 $), \mathrm{P}_{2}=75 \%$ recommended dosage of manure $(15$ tons ha-1 $)+$ $25 \%$ recommended dosage of mineral fertilizer $\left(25 \mathrm{~kg}\right.$ urea ha ${ }^{-1}, 25 \mathrm{~kg} \mathrm{SP}-36 \mathrm{ha}^{-1}$ and $\left.37.5 \mathrm{~kg} \mathrm{KCl} \mathrm{ha}^{-1}\right), \mathrm{P}_{3}=50 \%$ recommended dosage of manure $\left(10\right.$ tons ha $\left.{ }^{-1}\right)+50 \%$ recommended dosage of mineral fertilizer $\left(50 \mathrm{~kg}^{2}\right.$ urea ha ${ }^{-1}, 50 \mathrm{~kg} \mathrm{SP}-36 \mathrm{ha}^{-1}$ and $\left.75 \mathrm{~kg} \mathrm{KCl} \mathrm{ha}^{-1}\right), \mathrm{P}_{4}=$ $25 \%$ recommended dosage of manure $\left(5\right.$ tons ha $\left.\mathrm{h}^{-1}\right)+75 \%$ recommended dosage of mineral fertilizer $\left(75 \mathrm{~kg} \mathrm{urea} \mathrm{ha}^{-1}, 75 \mathrm{~kg} \mathrm{SP}_{-} 36 \mathrm{ha}^{-1}\right.$ and $\left.112.5 \mathrm{~kg} \mathrm{KCl} \mathrm{ha}^{-1}\right)$, and $\mathrm{P}^{5}=100 \%$ recommended dosage of mineral fertilizer (100 kg urea ha $\mathrm{kg}^{-1}, 100 \mathrm{~kg} \mathrm{SP}-36 \mathrm{ha}^{-1}, 150 \mathrm{~kg} \mathrm{KCl} \mathrm{ha}$ ${ }^{1}$ ). The results showed that $\mathrm{P}_{1}$ and $\mathrm{P}_{2}$ treatments produced the highest contents of organic-C, total-N, available-P, exchangeable-K and soil Cation Exchange Capacity. However, the highest tuber weight was obtained in treatment $\mathrm{P}_{3}$. These results indicated that the combination of $50 \%$ recommended manure dosage $\left(10\right.$ tons ha $\left.{ }^{-1}\right)+50 \%$ recommended mineral fertilizer dosage $\left(50 \mathrm{~kg}\right.$ urea ha ${ }^{-1}, 50 \mathrm{~kg}$ $\mathrm{SP}-36 \mathrm{ha}^{-1}$ and $75 \mathrm{~kg} \mathrm{KCl} \mathrm{ha}^{-1}$ ) could provide a balanced nutrient content in sufficient quantities that meet the sweet potato requirements from the early growth stage to the tuber formation stage, and create soil physical conditions that support the sweet potato tuber development.
\end{abstract}

Keywords: Purple fleshed sweet potato, soil chemistry

\section{INTRODUCTION}

Sweet potato (Ipomoea batatas L. (Lam) is one of the potential food crops that can be used as the main staple food - other than rice and corn - since the sweet potato tuber contains high carbohydrates $( \pm 28 \%)$. In Indonesia, the average national sweet potato productivity is about $16 \mathrm{t}$ $\mathrm{ha}^{-1}$, which is still far below the potential yield of superior varieties of sweet potatoes which can reach $25-40 \mathrm{t} \mathrm{ha}^{-1}$ (BP 2015). The low productivity of sweet potato in Indonesia, particularly in the dryland region such as East Nusa Tenggara (NTT) Province, is caused by many factors, including poor soils and crop management, especially fertilizer application. In general, farmers do not apply fertilizers for sweet potato crop, although there are many sources of fertilizer, such as cattle manure that is abundantly available in the vicinity of agricultural areas and settlements.

The nutrient requirement in sweet potato cultivation can be met through a combination of organic and inorganic/chemical fertilizers. The use of organic fertilizer can improve soil structure, and eventually provide better root growth. Furthermore, inorganic fertilization can fulfill the high nutritional needs of sweet potatoes. This high nutrient requirement can not be met only by providing organic fertilization, except if it is provided in a high dosage which often cannot be afforded by the farmers. The combination of inorganic/chemical fertilizers and organic fertilizers is an ideal alternative as these fertilizers combinations are able to meet the needs of the crop and also can maintain sustainable production and soil fertility.

The effect of a combination of inorganic and organic fertilizers on sweet potatoes has been reported by many studies. Salawu and Muktar (2008) recommended the use of 5 to $10 \mathrm{t} \mathrm{ha}^{-1}$ cattle manure combined with NPK inorganic fertilizer. Meanwhile, the combination of NPK $(15: 15: 15)$ at rates of $300 \mathrm{~kg} \mathrm{ha}^{-1}$ with $3.2 \mathrm{t} \mathrm{ha}^{-1}$ of chicken manure produced the highest sweet potato yield in Ultisols (Omenka et al. 2012). This study also recommended the application of a combination of moderate rates of inorganic fertilizers (150-300 kg NPK ha ${ }^{-1}$ ) with 2-3 $\mathrm{t} \mathrm{ha}^{-1}$ of manure for sweet potato cultivation in Ultisols with low to moderate soil fertility.

In Indonesia, in general, the recommended inorganic fertilizer rate for sweet potato fertilization is $100-150 \mathrm{~kg}$ of 
Urea $+100 \mathrm{~kg} \mathrm{SP}-36+150 \mathrm{~kg} \mathrm{KCl}-\mathrm{ha}^{-1}$ (Saleh et al. 2008). However, the application of such fertilizers is also recommended to be applied in combination with organic fertilizers, such as manure, with rates of 3-5 $\mathrm{t} \mathrm{ha}^{-1}$. Many studies have also been carried out under proportional combination of organic and inorganic fertilizers on sweet potatoes. However, study on the effect of these fertilizers combination on a specific variety of purple sweet potato particularly in the dryland region with alkaline soils such as in East Nusa Tenggara Province, Indonesia is limited. The present study was aimed to (i) evaluate the effect of a combination of organic (cattle manure) and inorganic fertilization on the soil physical and chemical properties and the yield of purple sweet potato, and (ii) identify the best fertilizer combination for purple sweet potato grown on alkaline soils.

\section{MATERIALS AND METHODS}

\section{Research location and materials}

The experiment was conducted in the Integrated Field Laboratory of Archipelagic Dryland Center of Excellence, Universitas Nusa Cendana, Kupang, East Nusa Tenggara, Indonesia (1009"15.34" $\mathrm{S}$ and 123 4012.47" E), commencing from November 2017 to March 2018. The average annual rainfall was $1,539 \mathrm{~mm}$ with the wet season occurring for three months from December to March/April. Average daily air temperature was $31^{\circ} \mathrm{C}$ and relative humidity was $82 \%$. The soil type is classified as a Typic Ustropept (Soil Survey Staff 1998) containing 34\% clay. Materials used in this study were a purple sweet potato variety, cattle manure, and inorganic/mineral (NPK) fertilizer.

\section{Experimental design}

The experiment was arranged in a Randomized Block Design with six treatments and four replicates. The assigned treatments were $\mathrm{P}_{0}=$ without manure and without mineral fertilizer (Control), $\mathrm{P}_{1}=100 \%$ recommended dosage of manure (20 tons $\left.\mathrm{ha}^{-1}\right), \mathrm{P}_{2}=75 \%$ recommended dosage of manure (15 tons $\left.\mathrm{ha}^{-1}\right)+25 \%$ recommended dosage of mineral fertilizer (25 kg urea ha-1 $25 \mathrm{~kg} \mathrm{SP-36}$ $\mathrm{ha}^{-1}$ and $\left.37.5 \mathrm{~kg} \mathrm{KCl} \mathrm{ha}^{-1}\right), \mathrm{P}_{3}=50 \%$ recommended dosage of manure $\left(10\right.$ tons $\left.\mathrm{ha}^{-1}\right)+50 \%$ recommended dosage of mineral fertilizer $\left(50 \mathrm{~kg}\right.$ urea ha ${ }^{-1}, 50 \mathrm{~kg} \mathrm{SP}-36 \mathrm{ha}^{-1}$ and 75 $\left.\mathrm{kg} \mathrm{KCl} \mathrm{ha}{ }^{-1}\right), \mathrm{P}_{4}=25 \%$ recommended dosage of manure $(5$ tons $\left.\mathrm{ha}^{-1}\right)+75 \%$ recommended dosage of mineral fertilizer

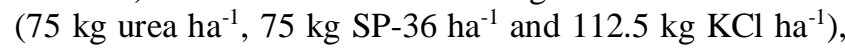
and $\mathrm{P}_{5}=100 \%$ recommended dosage of mineral fertilizer (100 kg urea ha-1, $100 \mathrm{~kg} \mathrm{SP-36} \mathrm{ha-1,} 150 \mathrm{~kg} \mathrm{KCl} \mathrm{ha}{ }^{-1}$ ). Each treatment had four replicates, thus, 24 experimental units were evaluated.

\section{Research procedures}

\section{Field preparation and plant cultivation}

The planting field was cleared from weeds, plowed as deep as $30-40 \mathrm{~cm}$, and then grazed. Twenty-four single row planting plots, each measuring $3 \mathrm{~m} \mathrm{x} 1 \mathrm{~m}$ with a $30 \mathrm{~cm}$ deep, were made. Space between blocks was $100 \mathrm{~cm}$ while between plot spacing was $70 \mathrm{~cm}$. At two weeks before planting, cattle manure was applied to each planting plot according to the treatment. The NPK fertilizers $(16: 16: 16)$ were applied at early planting time with rates according to the treatment assigned.

Sweet potato stems were cut into $25-30 \mathrm{~cm}$ in length with 4-5 nodes each was used in the experiment. The cutting stems were produced from two months old purple sweet potato plant. Each plot was planted with 5 cuttings with a spacing of $50 \mathrm{~cm}$ within the plot. Each planting hole was planted with one cutting. One-third or 1-2 nodes of lower part of the cutting were inserted into the planting hole, and the remaining two-thirds of the cutting was left above the ground. Irrigation was done twice a day to reach a field capacity level. Weeding was carried out manually using hand or knife. Harvesting was done four months after planting.

\section{Soil sampling and laboratory analysis}

Sampling of soil for chemical analysis was done before planting and after harvesting period. Chemical property analysis of cattle manure was done before planting sweet potato. Soil samples were taken from each planting plot.

Soil samples and cattle manure were sieved $(1.0 \mathrm{~mm})$. $\mathrm{pH}-\mathrm{H}_{2} \mathrm{O}(1: 10 \mathrm{w} / \mathrm{v})$ was measured using a $\mathrm{pH}$ meter (Jenway 3305), C-organic was determined based on the Walkley and Black method (Association of Official Agriculture Chemists 2002), total nitrogen was determined - using the Kjeldahl method (American Society of Agronomy and Soil, 1982), Available-P was determined using Olsen method and measured by using a spectrometer (Spectronic $21 \mathrm{D}), \mathrm{K}$ was extracted based on the basic oxidation method with $\mathrm{HNO}_{3}$ and $\mathrm{HClO}_{4}$ (Association Official Agriculture Chemists 2002) and measured by using an AAS

\section{Variables and data analysis}

Observed data included chemical properties of soil before planting and at harvest, nutrients content $(\mathrm{N}, \mathrm{P}, \mathrm{K})$ of cattle manure, and fresh tuber yield of sweet potato. Fresh tuber yield was harvested from each planting plot and weighed. Only the marketable tuber yield $(\geq 200 \mathrm{~g}$ each) was included in the measurement of tuber yield. Observed data were subjected to Analysis of Variance (ANOVA) according to the assigned treatment following the procedure in Gasperz (1992). A Duncan Test (DMRT) (5\% significance level) was used to separate the treatment means.

\section{RESULTS AND DISCUSSION}

\section{Chemical properties of soil and cattle manure (before experiment)}

Chemical properties of the soils and cattle manure are presented in Table 1. This table shows that before planting, the soil $\mathrm{pH}\left(\mathrm{H}_{2} \mathrm{O}\right)$ was 7.7 , C-organic content was $0.26 \%$, available $\mathrm{P}$ (Olsen) was $9.28 \mathrm{ppm}, \mathrm{CEC}$ was $31.67 \mathrm{cmol}$ $\mathrm{kg}^{-1}$ and $\mathrm{K}$ content was $0.87 \mathrm{cmol} \mathrm{kg}$. The chemical properties of cattle manure used were $\mathrm{pH}\left(\mathrm{H}_{2} \mathrm{O}\right)$ 7.8, organic- $\mathrm{C}$ content was $30.9 \%$, total- $\mathrm{N}$ was $1.66 \%$, available 
$\mathrm{P}$ was $0.22 \%$, CEC was $113.33 \mathrm{cmol} \mathrm{kg}^{-1}$ and exchanged $\mathrm{K}$ was $110 \%$. The chemical characteristics of soil and cattle manure are presented in Table 1.

\section{Chemical properties of soil at harvest and sweet potato yield}

The effect of combination of cattle manure and NPK mineral fertilizer treatment on soil chemical properties and sweet potato tuber yield is presented in Table 2. ANOVA results showed that cattle manure and mineral NPK fertilizer significantly or highly significantly affected both soil chemical properties at harvest as well as purple sweet potato tuber yield.

The experimental results presented in Table 2 show that the application of cattle manure and inorganic fertilizer into the soil increased the content of organic-C, total $\mathrm{N}$, available $\mathrm{P}$, exchanged-K contents as well as soil Cation Exchange Capacity (CEC). The highest content of C, N, P, $\mathrm{K}$, and CEC was observed in the treatment of $\mathrm{P}_{1}\left(20 \mathrm{t} \mathrm{ha}^{-1}\right.$ cattle manure $)$ and $\mathrm{P}_{2}\left(15 \mathrm{t} \mathrm{ha}^{-1}\right.$ cattle manure $+25 \mathrm{~kg}$ urea $\mathrm{ha}^{-1}, 25 \mathrm{~kg} \mathrm{SP}-36 \mathrm{ha}^{-1}$ and $37.5 \mathrm{~kg} \mathrm{KCl} \mathrm{ha}^{-1}$ ).

The organic-C content of manure used was $30.86 \%$, so the application of cattle manure at a dosage of $20 \mathrm{t} \mathrm{ha}^{-1}$ was equivalent to $6,172 \mathrm{~kg}$ org-C ha-1, while the dose of $15 \mathrm{t}$ ha 1 of manure was equivalent to $4,629 \mathrm{~kg}$ org-C ha-1. Decomposition of organic matter is a fundamental process that occurs when the material is immersed in the soil. Some of the immersed organic material will be utilized by soil microorganisms as an energy source; some are oxidized and produce $\mathrm{CO}_{2}$ emissions into the atmosphere, some of the organic matter, altogether with microorganisms, will die and become residues left in the soil. In line with the decomposition process of manure occurs in the soil, Nur et al. (2014) reported that decomposed cattle manure lost about $1.42 \ln (\mathrm{t}) \%$ organic-C per day, and after 120 days, the loss of organic-C reached $36.5 \%$, meaning that $63.5 \%$ of organic-C are still stored in compost material. Therefore, manure that is immersed in the soil will undergo a gradual decomposition, and after 120 days, it will leave a residue thereby increasing the soil's organic-C content.
The data in Table 2 also shows that the use of manure as a soil conditioner affects the soil total $\mathrm{N}$ content. The highest soil total $\mathrm{N}$ content was observed in treatments $\mathrm{P}_{1}$ and $\mathrm{P}_{2}$ (application of cattle manure at a dosage of $20 \mathrm{t} \mathrm{ha}^{-1}$ and $\left.15 \mathrm{t} \mathrm{ha}^{-1}\right)$. This is because the nitrogen content of cattle manure is $1.66 \%$ so that a dosage of $20 \mathrm{t} \mathrm{ha}^{-1}$ is equivalent to $332 \mathrm{~kg} \mathrm{~N} \mathrm{ha}^{-1}$ or similar to $738 \mathrm{~kg}$ urea ha-1. Meanwhile, cattle manure at a dose of 15 tons $\mathrm{ha}^{-1}$ is equivalent to administering $249 \mathrm{~kg} \mathrm{~N}^{-1}$ or $554 \mathrm{~kg}^{-1}$ urea ha ${ }^{-1}$. Manure applied to the soil will undergo decomposition, some of the Nitrogen is used by microorganisms for its growth, some will be absorbed by plant roots, some will be washed away with drainage water and some others will experience volatilization into the atmosphere in the form of $\mathrm{NH}_{3}$. According to Tiquia and Tam (2000), initial C:N ratio of composted material below 20:1 contributed significantly to Nitrogen loss through $\mathrm{NH}_{3}$ volatilization. (C: $\mathrm{N}$ ratio of manure used was 18.59). When soil organisms die, together with $\mathrm{N}$ residues from existing manure will contribute to soil total N. In line with the process of decomposition of manure that occurs in the soil, Nur et al. (2014) reported that decomposed manure experienced a total N-loss of $39.1 \%$ during 120 days of decomposition, implying that $60.9 \%$ of total $\mathrm{N}$ was still stored in compost material. Manure that is immersed in the soil, therefore, will undergo a gradual decomposition, and after 120 days, it will leave a residue, thus, increases the soil's total-N content.

Table 1. Chemical properties of soil (before planting) and cattle manure

\begin{tabular}{lcc}
\hline Chemical property & Soil & Cattle manure \\
\hline Organic- $\mathrm{C}(\%)$ & 1.30 & 30.86 \\
Total N $(\%)$ & 0.26 & 1.66 \\
C/N ratio & 5.00 & 18.59 \\
P-available (Olsen) $(\mathrm{ppm})$ & 9.28 & - \\
$(\%)$ & - & 0.22 \\
Exchangeable-K $\left(\mathrm{cmol} \mathrm{kg}^{-1}\right)$ & 0.87 & - \\
$(\%)$ & - & 1.10 \\
$\mathrm{CEC}(\mathrm{cmol} \mathrm{kg}-1)$ & 31.67 & 113.33 \\
$\mathrm{pH}\left(\mathrm{H}_{2} \mathrm{O}\right)$ & 7.75 & 7.8 \\
\hline
\end{tabular}

Table 2. Effect of combined treatment of cattle manure and NPK mineral fertilizer on soil chemical properties and tuber yield of purple sweet potato

\begin{tabular}{|c|c|c|c|c|c|c|}
\hline Treatment & Org-C (\%) & $\begin{array}{l}\text { Total-N } \\
(\%)\end{array}$ & $\begin{array}{l}\begin{array}{l}\text { Available-P } \\
\text { (ppm) }\end{array} \\
\end{array}$ & $\begin{array}{l}\begin{array}{l}\text { Exch-K } \\
\left(\mathrm{cmol} \mathrm{kg}^{-1}\right)\end{array} \\
\end{array}$ & $\begin{array}{l}\text { CEC } \\
\left(\mathrm{cmol} \mathrm{kg}^{-1}\right)\end{array}$ & Tuber yield (kg per plant) \\
\hline $\mathrm{P}_{0}$ & $1.25 \mathrm{a}$ & $0.14 \mathrm{a}$ & $20.95 \mathrm{a}$ & $0.68 \mathrm{a}$ & $33.67 \mathrm{a}$ & $0.85 \mathrm{a}$ \\
\hline $\mathrm{P}_{1}$ & $1.67 \mathrm{~b}$ & $0.29 \mathrm{c}$ & $33.96 \mathrm{~d}$ & $1.16 \mathrm{~d}$ & $41.76 \mathrm{~b}$ & $0.95 \mathrm{a}$ \\
\hline $\mathrm{P}_{2}$ & $1.60 \mathrm{~b}$ & $0.28 \mathrm{c}$ & $32.16 \mathrm{~cd}$ & $1.15 \mathrm{~cd}$ & $41.38 \mathrm{~b}$ & $0.93 \mathrm{a}$ \\
\hline $\mathrm{P}_{3}$ & $1.53 \mathrm{~b}$ & $0.26 \mathrm{bc}$ & $29.25 \mathrm{c}$ & $1.11 \mathrm{~b}$ & $38.99 \mathrm{a}$ & $1.36 \mathrm{~b}$ \\
\hline $\mathrm{P}_{4}$ & $1.46 \mathrm{ab}$ & $0.22 \mathrm{~b}$ & $25.89 \mathrm{~b}$ & $0.99 \mathrm{~b}$ & $35.71 \mathrm{a}$ & $0.94 \mathrm{a}$ \\
\hline $\mathrm{P}_{5}$ & $1.22 \mathrm{a}$ & $0.16 \mathrm{a}$ & $22.53 \mathrm{a}$ & $0.74 \mathrm{a}$ & $33.51 \mathrm{a}$ & $1.06 \mathrm{a}$ \\
\hline
\end{tabular}

Note: Numbers within the same column followed by the same letter(s) are not significantly different at 0.05 DMRT. $\mathrm{P}_{0}:$ without manure and without mineral fertilizer. $\mathrm{P}_{1}: 100 \%$ recommended dosage of manure (20 tons ha $\left.{ }^{-1}\right) . \mathrm{P}_{2}: 75 \%$ recommended dosage of manure (15 tons $\left.\mathrm{ha}^{-1}\right)+25 \%$ recommended dosage of mineral fertilizer $\left(25 \mathrm{~kg}\right.$ urea ha ${ }^{-1}, 25 \mathrm{~kg} \mathrm{SP}-36 \mathrm{ha}^{-1}$ and $\left.37.5 \mathrm{~kg} \mathrm{KCl} \mathrm{ha}{ }^{-1}\right) . \mathrm{P}_{3}: 50 \%$

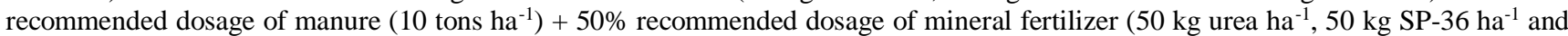
$\left.75 \mathrm{~kg} \mathrm{KCl} \mathrm{ha}^{-1}\right) \cdot \mathrm{P}_{4}: 25 \%$ recommended dosage of manure $\left(5\right.$ tons ha-1) $+75 \%$ recommended dosage of mineral fertilizer $\left(75 \mathrm{~kg}^{-1}\right.$ urea ha$1,75 \mathrm{~kg} \mathrm{SP}-36 \mathrm{ha}^{-1}$ and $\left.112.5 \mathrm{~kg} \mathrm{KCl} \mathrm{ha}^{-1}\right)$. P5: 100\% recommended dosage of mineral fertilizer (100 kg urea ha-1, $100 \mathrm{~kg} \mathrm{SP}^{-36} \mathrm{ha}^{-1}$, $150 \mathrm{~kg} \mathrm{KCl} \mathrm{ha}^{-1}$ ) 
The application of manure also increased the available $\mathrm{P}$ content of the soil (Table 2), and the highest increase in available $\mathrm{P}$ occurred in treatments $\mathrm{P}_{1}$ and $\mathrm{P}_{2}$ (application of cattle manure at a dosage of $20 \mathrm{t} \mathrm{ha}^{-1}$ and $15 \mathrm{t} \mathrm{ha}^{-1}$, respectively). The phosphorus content in manure was $0.22 \%$, thus, a dose of $20 \mathrm{t} \mathrm{ha}^{-1}$ is equivalent to $44 \mathrm{~kg} \mathrm{P} \mathrm{ha}^{-1}$ or $140 \mathrm{~kg} \mathrm{SP}-36 \mathrm{ha}^{-1}$. Whereas, a dose of $15 \mathrm{t}_{\text {manure ha- }} \mathrm{h}^{-1}$ is equivalent to $33 \mathrm{~kg} \mathrm{P} \mathrm{ha}^{-1}$ or $105 \mathrm{~kg} \mathrm{SP}-36 \mathrm{ha}^{-1}$. The soil of the experiment site was calcareous with a very high total $\mathrm{P}$ content (417.28 ppm). Although the total $\mathrm{P}$ content of the soil was very high, the available $\mathrm{P}$ was very low $(9.28$ ppm) or only about $2.2 \%$ of the total P (Nur 2014, 2015). Manure applied to the soil during decomposition will produce humic acid and fulvic acid, which can chelate calcium in the soil so that the $\mathrm{P}$ sorption by $\mathrm{Ca}$ decreases and, hence, the availability of P increases. Nur et al. (2014) reported that the $\mathrm{P}$ content available in calcareous soil could be increased by $43.6 \%$ by applying cattle manure compost.

Data in Table 2 also shows that the use of manure as soil ameliorant affected soil exchangeable $\mathrm{K}$ content. The highest soil exch.-K content was observed in $\mathrm{P}_{1}$ and $\mathrm{P}_{2}$ treatments (application of cattle manure at a dosage of $20 \mathrm{t}$ $\mathrm{ha}^{-1}$ and $15 \mathrm{t} \mathrm{ha}^{-1}$, respectively). High exch-K content in these two treatments did occur because the potassium content of manure was $1.10 \%$, thus, a dose of 20 tons ha ${ }^{-1}$ is equivalent to application of $220 \mathrm{~kg} \mathrm{~K} \mathrm{ha}^{-1}$ or $530 \mathrm{~kg} \mathrm{KCl}$ $\mathrm{ha}^{-1}$. A manure dose of $15 \mathrm{tha}^{-1}$ is equivalent to application of $165 \mathrm{~kg} \mathrm{~K} \mathrm{ha}^{-1}$ or $398 \mathrm{~kg} \mathrm{SP-36} \mathrm{ha-1}$.

The application of manure also increased soil CEC content (Table 2). The highest increase in CEC occurred in treatments $\mathrm{P}_{1}$ and $\mathrm{P}_{2}$ (application of cattle manure at a dosage of $20 \mathrm{t} \mathrm{ha}^{-1}$ and $15 \mathrm{tha}^{-1}$, respectively). The increase in CEC of soil fed with manure is thought to originate from oxidation of the carboxyl, phenolic and alcoholic groups possessed by humic and fulvic acids produced in the decomposition process of the manure. According to Stevenson (1994), humic acid and fulvic acid have a chemical structure similar to the same $\mathrm{OH}$-phenolic acidity (310 $\mathrm{cmol} \mathrm{kg}^{-1}$ ), however, fulvic acid has higher $\mathrm{OH}-$ alcoholic acidity $\left(500 \mathrm{cmol} \mathrm{kg}^{-1}\right)$ than humic acid (260 $\mathrm{cmol} \mathrm{kg}^{-1}$ ).

Although the improvement in soil chemical properties (increase in content of $\mathrm{C}, \mathrm{N}, \mathrm{P}, \mathrm{K}$ and $\mathrm{CEC}$ ) occurred the best in $\mathrm{P}_{1}$ and $\mathrm{P}_{2}$ treatments (application of cattle manure at a dosage of $20 \mathrm{t} \mathrm{ha}^{-1}$ and $15 \mathrm{t} \mathrm{ha}^{-1}$, respectively), data in Table 2 shows that the highest purple sweet potato tuber yield was produced not in $\mathrm{P}_{1}$ and $\mathrm{P}_{2}$ treatments but in $\mathrm{P}_{3}$ treatment (application of $50 \%$ manure or 10 tons ha $\mathrm{ha}^{-1}+50$ $\mathrm{kg}$ Urea ha ${ }^{-1}, 50 \mathrm{~kg} \mathrm{SP}-36 \mathrm{ha}^{-1}$ and $75 \mathrm{~kg} \mathrm{KCl} \mathrm{ha}^{-1}$ ). These results indicate that a combination of $50 \%$ recommended dosage of manure $+50 \%$ recommended dosage of mineral fertilizer was able to provide a nutrient balance in an adequate amount of sweet potato requirements from the early growth to the formation of tubers, and created a physical condition of the soil that supports tuber development. In the early period of sweet potato growth, the cattle manure was just started to decompose (mineralization), thus, it has not been able to provide sufficient quantity of nutrients to support optimum plant growth; the role of manure as a nutrient source is carried out by inorganic fertilizers or mineral fertilizers. In this circumstance, the role of fertilizer as nutrient provider can be prepared through a combination of organic fertilizer and inorganic fertilizer throughout the vegetative growth phase until tuber formation and enlargement phases.

In conclusion, based on the present study results and discussion, it can be concluded that the treatments of $\mathrm{P}_{1}(20$ tons ha $\left.{ }^{-1}\right)$ and $\mathrm{P}_{2}\left(15\right.$ tons manure ha ${ }^{-1}+25 \mathrm{~kg}$ urea ha ${ }^{-1}+$ $25 \mathrm{~kg} \mathrm{SP}-36 \mathrm{ha}^{-1}+37.5 \mathrm{~kg} \mathrm{KCl} \mathrm{ha}^{-1}$ ) produced the highest C-organic, total $\mathrm{N}$, available $\mathrm{P}$, and exch-K and CEC. However, the highest tuber yield was obtained at $\mathrm{P}_{3}$ treatment (10 tons manure ha ${ }^{-1}+50 \mathrm{~kg}$ urea ha $\mathrm{ha}^{-1}+50 \mathrm{~kg}$ SP-36 ha h $\left.^{-1} 75 \mathrm{~kg} \mathrm{KCl} \mathrm{ha}{ }^{-1}\right)$. A combination of $50 \%$ recommended rates of manure $\left(10 \mathrm{t} \mathrm{ha}^{-1}\right)+50 \%$ recommended rates of mineral fertilizer $\left(50 \mathrm{~kg}\right.$ Urea ha- ${ }^{-1}$, $50 \mathrm{~kg} \mathrm{SP}-36 \mathrm{ha}^{-1}$ and $75 \mathrm{~kg} \mathrm{KCl} \mathrm{ha}^{-1}$ ) was able to provide nutrient balance in a sufficient amount of purple-fleshed sweet potato requirements from the initial growth period to the tuber formation period, and created soil physical conditions that support the tuber development.

\section{REFERENCES}

Association Official Agriculture Chemists. 2002. Official Methods of Analysis of AOAC International. Volume I.P. 2.5-2.37. In: Horwitz W (ed.). Agricultural Chemicals, Contaminants, Drugs. $17^{\text {th }}$ ed. AOAC International, Maryland, USA.

Nur MSM, Islami T, Handayanto E, Nugroho WH, Utomo WH. 2014. The Use of Biochar Fortified Compost on Calcareous Soil of East Nusa Tenggara, Indonesia: 2. Effect on the Yield of Maize (Zea Mays L.) and Phosphate Absorption. Amer-Eurasian J Sustain Agric 8 (5): 105111.

Nur MSM, Utomo WH, Handayanto E, Nugroho WH, Islami T. 2014. The Use of Biochar Fortified Compost on Calcareous Soil of East Nusa Tenggara, Indonesia: 1. Evolution of organic matter and nitrogen on composting of farmyard manure (FYM) and Siam weed (Chromolaena odorata L.) biomass added with biochar as a bulking agent. Adv Nat Appl Sci 8 (8): 175-182.

Nur MSM. 2014. Pengaruh Penggunaan Kompos Diperkaya Biochar Sebagai Bulking Agent terhadap Serapan Fosfor dan Hasil Jagung (Zea mays L.) pada Calcarosol di Timor Barat. [Dissertation]. PPs, Fakultas Pertanian, Univ. Brawijaya, Malang. [Indonesian]

Nur MSM. 2015. Pengaruh Bahan Humat Ekstrak Kompos terhadap P Terjerap dan P Tersedia pada Calcarosol. Prosiding Seminar Nasional Pertanian Mewujudkan Ketahanan Pangan Melalui Pengelolaan Sumberdaya Alam dan Peningkatan Ketahanan Hayati. Fakultas Pertanian Undana, Kupang. [Indonesian]

Omenka NA, Chuckwu LL, Mbanasor EO, Ebeniro CN. 2012. Effect of organic and inorganic fertilizer and time of application on soil properties and yield of sweet potato in a tropical ultisol. J.of Agric and Social Res 12 (1): 183-193.

Salawu IS, Mukhtar AA. 2008. Reducing the dimension of growth and yield characters of sweet potato varieties as affected by varying rates of organic and inorganic fertilizer. Asian J Agric Res 2 (1): 41-44. DOI: 10.3923/ajar.2008.41.44

Saleh N, Rahayuningih SA, Widodo Y. 2008. Profil dan peluang pengembangan ubi jalar untuk mendukung ketahanan pangan dan agroindustri. Bul. Palawija 15: 21-30. [Indonesian]

Soil Survey Staff. 1998. Keys to Soil Taxonomy, 8th ed. Natural Resources Conservation Service, United States Department of Agriculture, Washington D.C.

Stevenson FJ. 1994. Humus Chemistry. Genesis, Composition, Reaction. $2^{\text {nd }}$ ed. John Wiley \& Sons. Inc., New York.

Tiquia SM, Tam NFY. 2000. Fate of nitrogen during composting of chicken litter. Environ Pollut 110: 535-541. DOI: 10.1016/S02697491(99)00319-X 